\title{
Iptek bagi Masyarakat Home Industri Keripik Bayam
}

\author{
Gati Sri Utami ${ }^{1}$, Azmuri Wahyu Azinar ${ }^{2}$ \\ ${ }^{1}$ Teknik Sipil, Institut Teknologi Adhitama Surabaya \\ fita.fina3@gmail.com \\ ${ }^{2}$ Teknik Informatika, Institut Teknologi Adhitama Surabaya \\ azmuri@itats.ac.id
}

\begin{abstract}
Home industry of spinach chips in Sidoarjo region is one type of business that contribute to support the economy of the community. With the increasing cost of living that makes people to always creatively increase family income. Likewise with partners in Science and Technology for Society (IbM) this. Partners in IbM This is Home Industry Spinach Spinach Sidoarjo area. In running its business, many problems faced by Partners. Problems to be solved by the Team and agreed upon by Partners include aspects of production, product and marketing. In the aspect of production is the process of draining the old oil and its products still remove the oil. Partner Pack 2 still uses thin plastic and has no design yet. The problem on the product aspect is Partner 2 product within 3 days is not tasty. This is different from the chips of spinach Mitra 1 that can last up to 1 month. Partner products are sometimes destroyed when deposited in a Store or Supermarket. The problem with the marketing aspect is the lack of knowledge in online marketing strategies. Based on these problems, the Team conducted assistance in these three aspects. The team buys oil slicers, gas stoves with high pressure, creates blogs at https://camilanqblog.wordpress.com, air filler syringes and marketing training or online marketing strategies for Partners 1. The team buys oil slicers, blenders and tools Fryers, high pressure gas cookers, air filler siler tools, packaging designs, savory and durable spinach making training, and marketing training or marketing strategies. After accompaniment, Partner spinach chips can survive within 1 month with reduced oil content, crushed spinach chips are also reduced and tasty. When the time drained faster, the knowledge of marketing-related Partners is increasing, partners began marketing the spinach chips in cooperation with the local store. Revenue from Partners has started to increase even though only $5 \%$.
\end{abstract}

Keywords: spinach chips, marketing, oil slicer, siler tool

\begin{abstract}
ABSTRAK
Home industri keripik bayam didaerah Sidoarjo merupakan salah satu jenis usaha yang ikut menyokong perekonomian masyarakat. Dengan semakin meningkatnya biaya hidup membuat masyarakat untuk selalu kreatif menambah pendapatan keluarga. Demikian juga dengan mitra pada Iptek bagi Masyarakat (IbM) ini. Mitra dalam IbM ini adalah Home Industri Keripik Bayam di daerah Sidoarjo. Dalam menjalankan usahanya, banyak permasalahan yang dihadapi oleh Mitra. Permasalahan yang akan diselesaikan oleh Tim dan sudah disepakati oleh Mitra mencakup aspek produksi, produk dan pemasaran. Pada aspek produksi adalah proses meniriskan minyak lama dan produknya masih mengeluarkan minyak. Kemasan Mitra 2 masih menggunakan plastik tipis dan belum punya desain. Permasalahan pada aspek produk adalah produk Mitra 2 dalam jangka waktu 3 hari sudah tidak gurih. Hal ini berbeda dengan keripik bayam Mitra 1 yang bisa bertahan sampai 1 bulan. Produk Mitra kadang hancur pada saat dititipkan di Toko atau Supermarket. Permasalahan pada aspek pemasaran adalah kurangnya pengetahuan dalam strategi pemasaran khususnya online. Berdasarkan permasalahan tersebut, Tim mengadakan pendampingan dalam ketiga aspek tersebut. Tim membelikan alat peniris minyak, kompor gas dengan tekanan tinggi, membuatkan blogs dengan alamat https://camilanqblog.wordpress.com, alat siler pengisi udara, dan pelatihan marketing atau strategi pemasaran khususnya online untuk Mitra 1. Tim membelikan alat peniris minyak, blender dan alat penggorengan, kompor gas bertekanan tinggi, alat siler pengisi udara, membuatkan desain kemasan, pelatihan pembuatan bayam yang gurih dan awet, dan pelatihan marketing atau strategi pemasaran. Setelah dilakukan pendampingan, keripik bayam Mitra bisa bertahan dalam jangka 1 bulan dengan kadar minyak berkurang, keripik bayam yang hancur juga berkurang dan gurih. Waktu meniriskan lebih cepat, pengetahuan Mitra terkait pemasaran semakin
\end{abstract}


bertambah, mitra mulai memasarkan keripik bayam bekerjasama dengan Toko setempat. Pendapatan dari Mitra sudah mulai mengalami kenaikan walaupun hanya 5\%.

Kata kunci: keripik bayam, pemasaran, alat peniris minyak, alat siler

\section{PENDAHULUAN}

Pemerintah Sidoarjo ingin menjadikan Sidoarjo sebagai kota UKM (dinas pariwisata, 2016). Sehingga banyak masyarakat yang sangat antusias untuk meningkatkan perekonomian dengan memulai usaha baru. Demikian juga dengan Mitra dalam pendampingan IbM adalah home industri keripik yang dikelola oleh Ibu Lia (Mitra 1) dan Ibu Sulis (Mitra 2). Pada saat merintis usaha, kedua Mitra mencari usaha yang bisa dijalankan dengan modal kecil. Kedua Mitra melihat bahwa bayam merupakan salah satu jenis sayuran yang kadang kurang disukai anak-anak. Padahal kandungan gizinya lengkap baik garam mineral maupun vitamin. Kandungan gizinya mulai kalori, protein, lemak, hidrat arang, Vitamin A, Vitamin B1, Vitamin C, Kalsium, Fosfor, Besi dan air. Selain itu bayam mengandung asam folat dan asam osalat yang dapat menurunkan kolesterol, mencegah sakit gusi, mengobati eksim dan asma, perawatan kulit muka, kulit kepala dan rambut (lktm-palembang, 2016).

Pendapatan kotor Mitra pada tahun 2016 tiap bulannya tidak lebih dari 5 juta, bahkan Mitra 2 hanya berkisar 2 jutaan. Keripik bayam pada Mitra 1 dikemas 100 gram dan $1 \mathrm{~kg}$. Harga kemasan 100 gram sebesar Rp. 7000,- sedangkan yang kemasan $1 \mathrm{~kg}$ harganya Rp. 44rb. Yang kemasan 1 $\mathrm{kg}$ biasanya dikemas ulang oleh pemesan dengan merk mereka. Tiap bulan rata-rata penjualan sekitar $60 \mathrm{~kg}$. Sedangkan Mitra 2 menjual keripik bayam dalam kemasan 100 gram, tetapi masih menggunakan plastik yang tipis dan tidak ada kemasannya. Harga perbungkusnya sebesar Rp. 5000. Dalam menjalankan usahanya kedua Mitra mengalami beberapa permasalahan. Jika bahan baku harganya mahal atau sulit didapat maka produksi kadang dihentikan sampai mendapatkan bayam yang terjangkau karena tidak mungkin mitra akan menjual dengan harga yang sama yang mengakibatkan penurunan laba bahkan rugi.

Selain itu kedua Mitra menemui beberapa permasalahan baik dalam aspek keuangan, produksi, produk maupun pemasaran. Dalam aspek keuangan adalah keterbatasan dana dan manajemen keuangan yang belum bagus. Dalam aspek produksi adalah pada saat proses meniriskan minyak keripik bayam membutuhkan waktu yang lama sampai 3 hari. Walaupun begitu keripik bayam masih mengeluarkan minyak dalam jangka waktu 2 minggu. Permasalahan aspek produk adalah keripik bayam Mitra 2 tidak gurih setelah 3 hari, keripik bayam ada yang hancur sehingga tidak bisa dijual, kemasan keripik bayam Mitra 2 masih menggunakan plastik dan tidak ada desainnya. Permasalahan pada aspek pemasaran adalah pengetahuan Mitra terkait pemasaran (strategi pemasaran) masih kurang khususnya pemasaran online. Dari beberapa permasalahan tersebut, Tim sepakat dengan Mitra untuk menyelesaikan sebagian dari permasalahan tersebut yaitu aspek produksi, produk dan pemasaran. Sehingga diharapkan tujuan dari adanya pendampingan ini adalah adanya peningkatan dalam pendapatan, kualitas produk dan kemampuan/pengetahuan Sumber Daya Manusia (SDM) dalam bidang produksi dan pemasaran dapat tercapai.

\section{METODE PELAKSANAAN}

Metode pelaksanaan kegiatan IbM adalah memberikan pendampingan kepada Mitra dalam tiga aspek, yaitu:

1. Aspek Produksi

Pada aspek produksi dilakukan pengadaan alat peniris minyak, kompor gas bertekanan tinggi, alat penggorengan dan blender. Selain itu diberikan pelatihan pembuatan keripik bayam yang gurih dan awet.

2. Aspek Produk

Pada aspek produk dilakukan pembuatan desain kemasan keripik bayam Mitra 2, pengadaan alat siler pengisi udara.

3. Aspek Pemasaran

Pada aspek pemasaran dilakukan pelatihan marketing (strategi pemasaran) khususnya pemasaran online dan pembuatan blogs Mitra 1. 
Model pendampingan dapat dilihat pada Gambar 1.

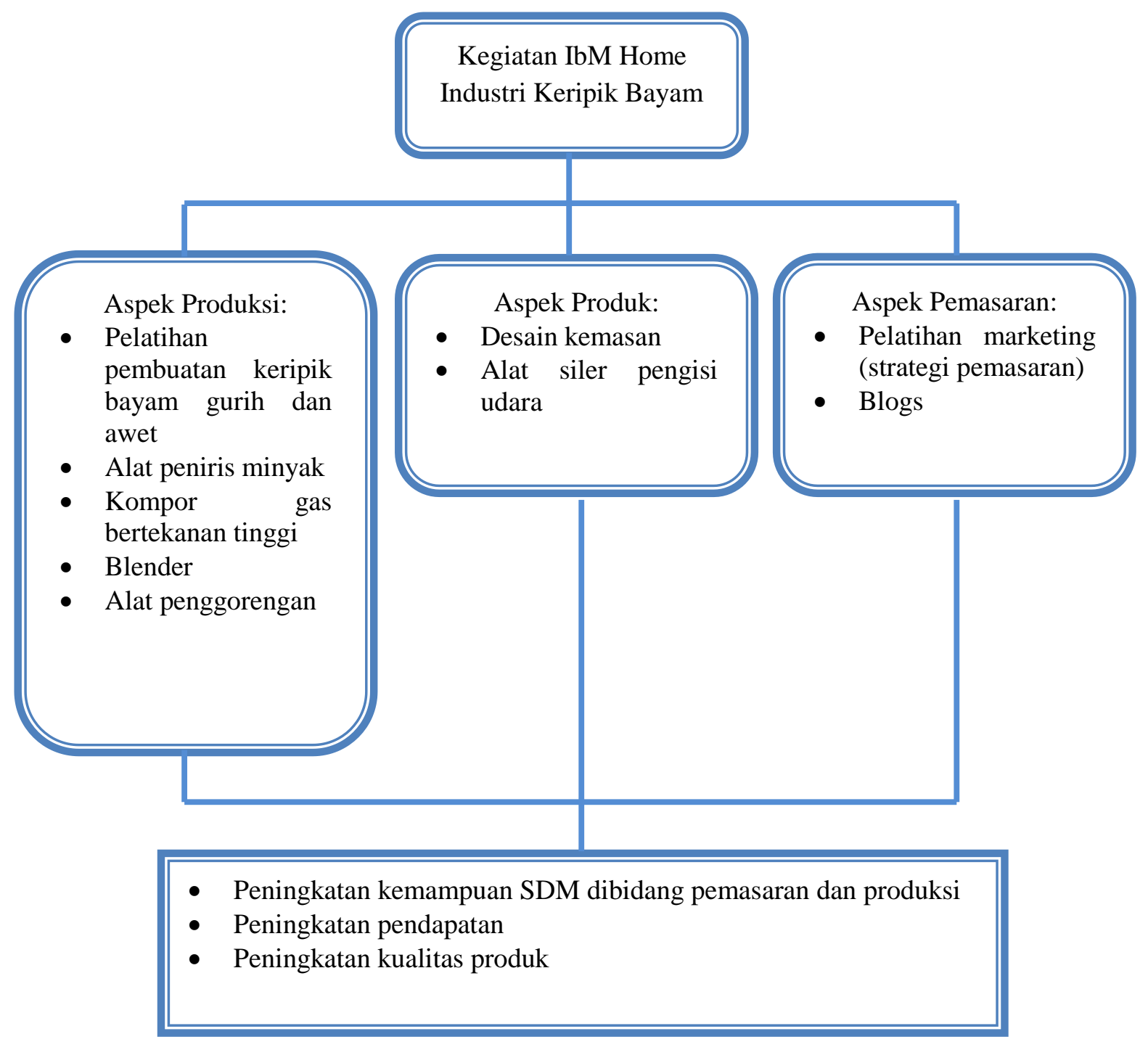

Gambar 1. Model pendampingan IbM

\section{HASIL DAN PEMBAHASAN}

Berdasarkan permasalahan yang terjadi pada Home Industri Keripik bayam, Tim mengadakan pendampingan sesuai dengan metode pelaksanaan yang sudah direncanakan dan disepakati. Pada aspek produksi telah dilakukan pengadaan alat peniris minyak, kompor gas bertekanan tinggi, alat penggorengan dan blender. Selain itu telah diadakan pelatihan pembuatan keripik bayam yang gurih dan awet. Tim meminta bantuan pemilik Mitra 1 sebagai trainer dikarenakan Ibu Lia pernah diundang oleh Dinas Koperasi atau Disperindag untuk mengadakan pelatihan pembuatan keripik bayam. Keripik bayam yang dihasilkan oleh Ibu Lia (Mitra 1) bisa bertahan sampai 1,5 bulan jika dalam kemasan tertutup rapat. Pelatihan dilakukan pada hari Minggu, 23 Juli 2017 selama satu hari. Pada pelatihan tersebut karyawan Mitra 2 tidak hanya diajari cara pembuatan keripik bayam tetapi juga diberikan pengalaman Ibu Lia saat merintis usaha keripik bayam. Pada aspek produk telah dilakukan pengadaan alat siler pengisi udara, pembuatan desain kemasan produk Mitra 2. 
Sedangkan pada aspek pemasaran telah dilakukan pelatihan marketing (strategi pemasaran) khususnya online. Dengan melihat kondisi Mitra khususnya Mitra 2 yang masih merintis dan pengetahuan terkait strategi pemasaran sangat kurang. Tim mengajari strategi pemasaran apa saja yang bisa diterapkan oleh Mitra. Bisa dengan bekerjasama dengan Toko ternama atau supermarket untuk memasarkan produknya. Mitra bisa mengikuti pameran yang diadakan oleh Disperindag, Dinas Koperasi atau intansi lain untuk memperkenalkan produknya. Selain itu bisa dilakukan secara online melalui facebooks, whattsapps, instagram atau blogs. Pelatihan dilakukan hanya sehari dan Mitra 1 yang dibuatkan blogs. Hal ini dikarenakan Mitra 1 sudah mulai menggunakan media online walau hanya whatsapps. Sedangkan Mitra 2 hanya menggunakan handphone untuk komunikasi saja bahkan ada yanng tidak punya. Tetapi pada saat pelatihan, semua diperkenalkan hal tersebut. Tim membuatkan blogs Mitra 1 dengan alamat: https://camilanqblog.wordpress.com . Tim terus mengadakan pendampingan dalam mengoperasikan dan mengelola blogs Mitra 1. Pendampingan yang sudah dilakukan dapat dilihat pada Gambar 2.

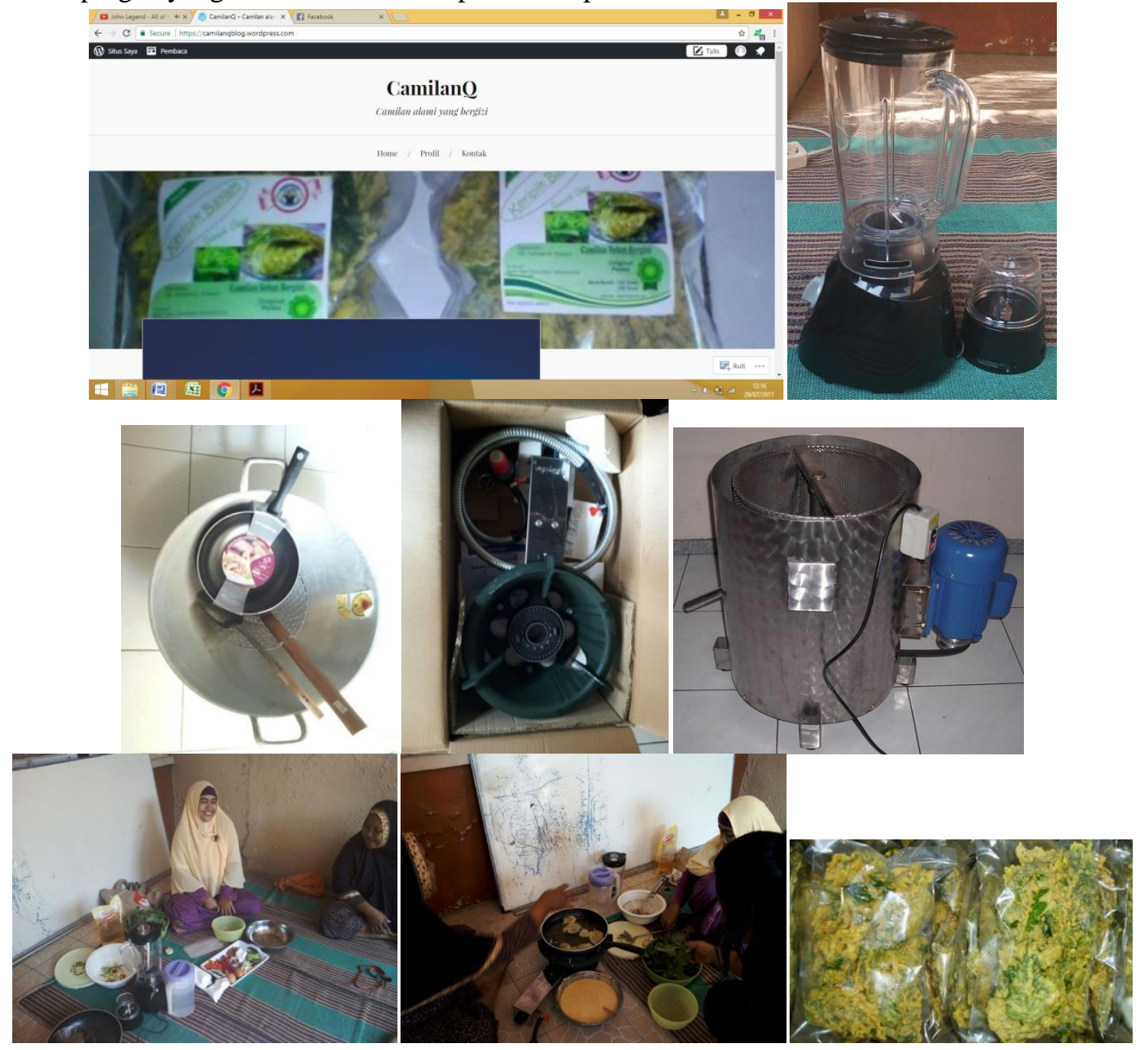

Gambar 2. Kegiatan pendampingan yang dilakukan pada Mitra IbM

Berdasarkan pendampingan yang telah dilakukan, kondisi Mitra sebelum dan setelah pendampingan sebagai berikut:

1. Sebelum pendampingan:

- Keripik bayam dalam kemasan masih mengandung minyak

- Keripik bayam tidak gurih dan tengik setelah 3 hari

- Belum mempunyai desain kemasan dan hanya dibungkus plastik tipis

- Pemasaran hanya dilakukan dari mulut ke mulut dan dijajakan ke pasar 
2. Setelah pendampingan:

- Kadar minyak mengalami penurunan dan bisa sampai 1 bulan

- Keripik bayam gurih dan tidak tengik sampai 1,5 bulan dalam kemasan tertutup rapat

- Sudah mempunyai desain kemasan dan produk dikemas plastik lebih tebal

- Pemasaran mulai dilakukan dengan menitipkan di toko sekitar, kantin rumah sakit serta Mitra 1 sudah mulai menggunakan media sosial.

Dari hasil pendampingan diharapkan ada peningkatan pendapatan dan kualitas produk serta kemampuan Mitra dalam bidang produksi dan pemasaran. Berdasarkan kondisi Mitra setelah dilakukan memang belum maksimal hasil yang dirasakan. Yang paling terasa dirasakan oleh Mitra adalah tidak adanya komplain terkait kandungan minyak yang ada pada keripik bayam. Selain itu keripik bayamnya juga gurih dan awet. Sehingga ada peningkatan pendapatan sekitar $5 \%$.

\section{KESIMPULAN}

Dari hasil dan pelaksanaan kegiatan yang dilakukan dapat disimpulkan bahwa: 1) Kegiatan yang sudah dilakukan dalam aspek produksi, produk dan pemasaran berupa pengadaan peralatan yang menunjang usaha dari Mitra maupun pelatihan bidang produksi dan pemasaran. 2) Setelah dilakukan pendampingan ada peningkatan pendapatan sebesar 5\% dikarenakan ada peningkatan kualitas produk, kemasan dan pengetahuan SDM bidang produksi dan pemasaran.

\section{UCAPAN TERIMA KASIH}

Ucapan terima kasih disampaikan kepada:

1. Bapak Prof. Ocky Karna Radjasa, M.Sc. selaku Direktur Riset dan Pengabdian Masyarakat Direktorat Jendral Penguatan Riset dan Pengembangan Kementrian Riset, Teknologi dan Pendidikan Tinggi.

2. Bapak Prof. DR. Ir. Suprapto, DEA selaku Koordinator Kopertis Wilayah VII Jawa Timur.

3. Bapak Syamsuri, ST., MT., Ph.D. selaku Rektor Institut Teknologi Adhi Tama Surabaya

4. Bapak Dr. Agus Budianto, MT. selaku Ketua Lembaga Penelitian dan Pengabdian Kepada Masyarakat (LPPM) Institut Teknologi Adhi Tama Surabaya

5. Ibu Dr. Yulfiah selaku Dekan Fakultas Teknik Sipil dan Perencanaan Institut Teknologi Adhi Tama Surabaya

\section{DAFTAR PUSTAKA}

http://pariwisata.sidoarjokab.go.id/wisata.php, diakses Maret 2016.

Rangkuti Freddy. (1997). Riset Pemasaran. PT Gramedia Pustaka Utama, Jakarta.

http://www.ukmsidoarjo.com. diakses Maret 2016.

www.lktm-palembang.com. Tanaman Berkasiat Obat. diakses Maret 2016. 
JPP IPTEK, November 2017, Vol. 1, No. 1

Halaman ini sengaja dikosongkan 